\title{
PENGARUH PERCEIVED RISK TERHADAP PEMBELIAN ONLINE MELALUI JEJARING SOSIAL FACEBOOK
}

\author{
Oleh : \\ Maulita* \\ Musdalifah* \\ ( ${ }^{\star}$ Dosen Politeknik Negeri Samarinda)
}

\begin{abstract}
ABSTRAK
Facebook merupakan salah satu media yang tidak hanya menyediakan fasilitas pertemanan tetapi juga memberikan fasilitas untuk melakukan pembelian secara online. Melalukan transaksi online melalui facebook memberikan beberapa kemudahan tetapi tetap saja mengandung unsur ketidakpastian sehingga menimbulkan resiko bagi konsumennya. Resiko dalam penelitian ini dilihat dari 8 dimensi yaitu Financial Risk, Psycological risk, Time risk, Privacy risk, Fraud risk, Product risk, Information risk, dan Delivery risk. Masing-masing dimensi ini diukur dengan menggunakan skala likert 1 sampai 6.

Populasi dan sampel dalam penelitian ini adalah mahasiswa Politeknik Negeri Samarinda yang pernah menggunakan facebook untuk melakukan transaksi pembelian online dan pengumpulan data dilakukan dengan metode survey. Sampel dalam penelitian ini sebanyak 150 orang. Analisis data yang digunakan dalam penelitian ini yaitu menggunakan regresi.

Hasil penelitian ini menunjukkan bahwa dari 8 dimensi resiko yang timbul dalam pembelian online, hanya fraud risk, information risk, dan delivery risk yang berpengaruh terhadap keputusan untuk melakukan pembelian produk online, sedangkan dimensi lainnya tidak berpengaruh.
\end{abstract}

Kata kunci : perceived risk, keputusan pembelian, facebook

\section{PENDAHULUAN}

Facebook tidak hanya media pertemanan namun dapat dimanfaatkan sebagai media perdagangan online. Perdagangan online melalui media facebook memiliki kemudahan, keuntungan, namun resiko tetap mengintai. Hal ini mengingat bahwa transaksi perdagangan online di media jejaring facebook berada di dunia maya, maka terdapat ketidakpastian yang sangat tinggi. Barang yang diperjualbelikan juga bersifat maya karena marang tersebut tersaji dalam bentuk informasi-informasi, baik berupa tulisan, foto ataupun vidio (Jarvenpaa dan Tractinsky, 1999). Konsumen tidak bisa benar-benar melihat, menyentuh, mendengar ataupun merasakan pengalaman terhadap barang yang akan dibelinya secara nyata.

Unsur ketidakpastian tersebut kemudian menimbulkan perceived risk dalam benak konsumen (Naiyi, 2004). Masih banyak konsumen yang menilai bahwa melakukan pembelian secara online memiliki resiko yang cukup signifikan. Baik berupa performance risk, financial risk, psychological risk, dan time risk harus diperhatikan dalam pembelian online (Stone dan Gronhaug, 1993). Perkembangan facebook sebagai media perdagangan online yang 
semakin meningkat walaupun tetap mengandung resiko yang kemudian membuat peneliti tertarik melakukan penelitian mengenai pengaruh resiko yang dirasakan (perceived risk) terhadap pembelian online di media jejaring sosial facebook.

\section{KAJIAN PUSTAKA}

\section{Sejarah Jejaring Sosial}

Sejak komputer dapat dihubungkan satu dengan lainnya dengan adanya internet banyak upaya awal untuk mendukung jejaring sosial melalui komunikasi antar komputer.NSitus jejaring sosial diawali oleh Classmates.com pada tahun 1995 yang berfokus pada hubungan antar mantan teman sekolah dan SixDegrees.com pada tahun 1997 yang membuat ikatan tidak langsung. Dua model berbeda dari jejaring sosial yang lahir sekitar pada tahun 1999 adalah berbasiskan kepercayaan yang dikembangkan oleh Epinions.com, dan jejaring sosial yang berbasiskan pertemanan seperti yang dikembangkan oleh Uskup Jonathan yang kemudian dipakai pada beberapa situs UK regional di antara 1999 dan 2001. Inovasi meliputi tidak hanya memperlihatkan siapa berteman dengan siapa, tetapi memberikan pengguna kontrol yang lebih akan isi dan hubungan. Pada tahun 2005, suatu layanan jejaring sosial MySpace, dilaporkan lebih banyak diakses dibandingkan Google dengan Facebook, pesaing yang tumbuh dengan cepat.

Jejaring sosial mulai menjadi bagian dari strategi internet bisnis sekitar tahun 2005 ketika Yahoo meluncurkan Yahoo! 360 ${ }^{\circ}$. Pada bulan juli 2005 News Corporation membeli MySpace, diikuti oleh ITV (UK) membeli Friends Reunited pada Desember 2005. Diperkirakan ada lebih dari 200 situs jejaring sosial menggunakan model jejaring sosial ini.dan saat ini jejaring yang saat ini sedang booming adalah Face book.

\section{Facebook}

Facebook adalah sebagai penyedia jejaring social yang menjadikan kita untuk saling berhubungan dengan teman, sesame pekerja, dan dengan orang lain yang senang dengan berbagi atau dari lapisan semua pengguna. Jadi jelaslah bahwa Facebook itu bukanlah "Halaman Buku" melainkan suatu situs komunitas dimana kita dapat saling berkomunikasi dengan pengguna lain di dunia maya. Facebook saat ini memang menjadi trend dalam situs social networking. Lebih lanjut dikatakan ada beberapa hal yang membuat Facebook menjadi trend di saat ini adalah antara lain :

1. Privacy : anggota bisa mengatur berbagai informasi yang boleh ditampilkan dan tidak boleh ditampilkan sampai mengatur siapa saja yang boleh melihatnya.

2. Feed : memberikan informasi yang terjadi pada jejaring facebook anda.

3. Mobile : dengan perangkat bergerak/ponsel kita bisa mengakses account Facebook.

4. Photo Album : jumlah foto yang bisa diupload tidak terbatas.

5. Status : dengan adanya pembuatan status yang bisa diberikan komentar, semakin membuat aktivitas jejaring akan semakin aktif.

6. Application : menyediakan aplikasi-aplikasi yang menyenangkan dan tidak membosankan. 
7. Advense (iklan) : dengan menggunakan Faceebook makan dapat membuat iklan dengan mudah dan bisa dengan mudah dan menghasilkan pendapatan dengan metode CPC (Cost per Clik).

\section{Electronic Commerce}

Electronic commerce didefnisikan beragam oleh para peneliti. Pada penelitian ini, penulis mengambil defenisi electronic commerce yang dikemukakan oleh Urbaczewski et al. (2002) yakni penggunaan jaringan computer untuk melakukan penjualan dan pembelian barang, jasa atau informasi secara elektronik dengan para supplier, konsumen atau competitor atau antar konsumen. Defenisi ini memerlukan dua persyaratan agar suatu perniagaan dapat disebut sebagai electronic commerce. Syarat pertama adalah perniagaan dilakukan secara online dan kedua yaitu adanya pertukaran nilai (exchange value).

Perniagaan secara online mengindikasikan adanya penggunaan jaringan computer yang menjadi dasar teknologi informasinya untuk mendukung akumulasi data, manipulasi atau komunikasi. Dimana jaringan yang digunakan bisa berupa jaringan terbuka seperti internet ataupun tertutup seperti intanet yang hanya digunakan kalangan tertentu yang dizinkan pengelola jaringan. Focus penelitian ini adalah jaringan terbuka yaitu internet melalui media jejaring social face book. Pertukaran nilai (exchange value) yang diakukan melalui electronic commerce melibatkan hal yang berkaitan dengan barang, jasa, informasi, uang dan waktu kenyamanan.

Tiga elemen berbeda yang ditemui di e-commerce. Pertama, vendor yakni organisasi atau orang yang menjual barang atau jasa secara elektronik. Maka disebut sebagai electronic vendor atau e-vendor. Kedua, konsumen yang menggunakan jasa elektronik untuk mencari informasi, memesan jasa atau membeli produk. Ketiga, teknologi berupa perangkat keras (computer, internet, telpon seluler), perangkat lunak yang dapat digunakan untuk bertransaksi (cowles et al. 2002).e-commerce berdasarkan pasarnya da dua kategori : business to business (B2B) dan e-commerce dan Business to consumer (B2C) ecommerce. Dan facebook adalah kategori B2C(Business to consumer).

\section{Perilaku Konsumen}

Perilaku konsumen berkaitan dengan perceived risk terutam dalam perilaku konsumen online dan proses pengambilan keputusan pembelian. Dengan memahami perilaku konsumen kita dapat mengetahui bagaimana proses pengambilan keputusan pembelian. Keputusan pembelian ini kemudian menentukan kepuasan konsumen dan resiko yang akan dirasakan konsumen apabila keputusan yang diambil tidak tepat.

Schiffman dan Kanuk (2008:6) mengatakan bahwa perilaku konsumen adalah perilaku yang ditampilkan oleh konsumen dalam mencari, membeli, menggunakan, mengevaluasi dan membuang produk, jasa dan ide-ide. Sedangkan menurut Loudon dan Bitta (2001:3) perilaku konsumen merupakan proses pengambilan keputusan dan kegiatan fisik individu yang terlibat dalam mengevaluasi, memperoleh, menggunakan, atau membuang barang dan jasa. Maka dapat dikatakan bahwa perilaku konsumen merupakan suatu proses yang menyangkut keputusan konsumen dalam melakukan pembelian, serta tindakan dalam memperoleh, memakai, mengkonsumsi, dan menghabiskan produk. 
Setiap hari kita membuat berbagai macam keputusan yang menyangkut segala kehidupan kita. Namun dalam membuat keputusan, kita tidak berpikir tentang bagaimana kita membuat keputusan tersebut dan apa saja yang terlibat dalam proses pengambilan keputusan itu sendiri. Menurut Kotler (2006:137) terdapat beberapa faktor yang mempengaruhi keputusan pembelian konsumen, yaitu fator budaya, sosial, pribadi, dan psikologi dari pembeli tersebut.

\section{Keputusan Pembelian Konsumen}

Secara umum, keputusan adalah pemilihan dari dua atau lebih alternatif pilihan (Schiffman dan Kanuk, 2008:437). Dengan kata lain untuk membuat keputusan harus terdapat alternative pilihan. Sebaliknya jika konsumen tidak memiliki alternatif untuk memilih maka tidak dapat dikategorikan sebagai pengambilan keputusan.. Menurut Schiffman dan kanuk (2008:438) pembuatan keputusan konsumen dapat dilihat sebagai 3 tahapan keputusan yang berbeda tetapi saling berhubungan, antara lain :

1. The input stage, tahapan ini mempengaruhi konsumen tentang kebutuhannya akan produk atau jasa yang terdiri dari 2 sumber informasi penting yaitu kegiatan pemasaran perusahaan dan lingkungan sosial budayanya. Pengaruh kumulatif dari dua hal tersebut yang menjadi masukan dalam mempengaruhi apa yang akan dibeli oleh konsumen dan bagaimana mereka menggunakan produk atau jasa yang mereka beli

2. The process stage, tahapan ini memfokuskan pada bagaimana konsumen membuat keputusan. Dalam diri setiap individu terjadi proses pengambilan keputusan yaitu bereaksinya area psikologis yang membuat konsumen sadar akan kebutuhan, kemudia konsumen mencari informasi ssebelum membeli dan terakhir mengevaluasi alternatif-alternatif yang ada. Konsumen juga dapat mengevaluasi pembelian dengan mempertimbangkan pengalaman membeli sebelumnya.

3. The output stage, setelah sebuah keputusan untuk membeli produk atau jasa tertentu, konsumen melakukan trial dan melakukan pembelian ulang. Langkah yang terakhir setelah membeli adalah mengevaluasi pembelian, dimana evaluasi pembelian ini akan dijadikan salah satu dasar bagi pengambilan keputusan pembelian berikutnya.

\section{Perilaku Konsumen Online}

Istilah konsumen sering diartikan sebagai dua jenis konsumen, yaitu konsumen individu dan konsumen organisasi. Barang dan jasa yang dibeli oleh konsumen individu dapat digunakan untuk diri sendiri, anggota keluarga atau diberikan pada orang lain sebagai hadiah. Dalam konteks barang dan jasa yang dibeli kemudian digunakan langsung oleh individu maka individu tersebut dinamakan pemakai akhir atau konsumen akhir. Konsumen organisasi meliputi organisasi bisnis, yayasan, lembaga sosial, kantor pemerintah dan lembaga lainnya yang membeli produk, peralatan dan jasa untuk menjalankan organisasinya.

Terdapat beberapa definisi perilaku konsumen. Definisi perilaku konsumen menurut Engel, et al. (1993:4) adalah sebagai berikut: "Consumer behavior as those activities directly involved in obtaining, consuming, and disposing of products and services, including the decision processes that precede and follow these actions". Schiffman dan Kanuk (1994:7), mendefinisikan perilaku konsumen sebagai berikut: "The term consumer behavior refers to the behavior that consumers display in searching for, 
purchasing, using, evaluating, and disposing of products and services that they expect will satisfy their needs". Wilkie (1990:12), mendefinikikan perilaku konsumen sebagai berikut: "The activities that people engage in when selecting, purchasing, and using product and services so as to satisfy needs and desires. Such activities involve mental and emotional processes, in addition to physical actions".

Berdasarkan pendapat para ahli di atas dapat disimpulkan bahwa perilaku konsumen online adalah tindakan-tindakan yang dilakukan oleh individu, kelompok atau organisasi yang berhubungan dengan proses pengambilan keputusan dalam mendapatkan barang secara online, menggunakan barangbarang atau jasa ekonomis yang dapat dipengaruhi oleh lingkungan.

\section{Perceived Risk}

Resiko yang dirasakan didefinisikan sebagai ketidakpastian yang dihadapi para konsumen jika mereka tidak dapat meramalkan konsekuensi keputusan mereka (Shiffman \& Kanuk, 2008). Dalam penelitian konsumen, risiko berarti situasi dimana konsumen tidak mengetahui konsekuensi dari alternatif atau kemungkinan terjadinya kerugian dari hasil pembelian yang dilakukan ( $\mathrm{Ha}$, 2002).

Resiko didefinisikan sebagai situasi dimana pembuat keputusan memiliki pengetahuan apriori konsekuensi yang merugikan dan kemungkinana terjadinya. Selain itu, ketidakpastian didefinisikan sebagai suatu situasi dimana pembuat keputusan tahu bahwa hasil yang mungkin untuk setiap alternatif dapat diidentifikasi, namu tidak ada pengetahuan tentang probabilitas yang melekat masing-masing (Shiffman \& Kanuk, 2008)

Perceived risk berarti keyakinan subyektif individu tentang potensi konsekuensi negatif dari keputusan yang diambil konusmen (M. Samadi dan A yaghoob-Nejadi, 2009). Harus ditekankan bahwa para konsumen dipengaruhi oleh berbagai resiko yang mereka rasakan, apakah resiko itu betul-betul ada atau tidak. Risiko yang dirasakan adalah konsep fundamental dan perilaku konsumen yang menyiratkan pengalaman konsumen pra-pembelian ketidakpastian mengenai jenis dan tingkat kerugian yang diperkirakan akibat dari pembelian dan penggunaan produk. Dalam penelitian ini, perceived risk didefinisikan sebagai potensi terjadinya kerugian atau konsekuensi negatif terhadap upaya untuk mendapatkan hasil yang diinginkan oleh konsumen dalam berbelanja secara online melalui media jejaring sosial facebook.

\section{Jenis-jenis Perceived Risk Konsumen}

Dalam penelitian yang dilakukan oleh Hanjun KO, Jaemin Jung, Joo Young Kim, dan Sung Wook Shim (2004) yang berjudul " Cross-cultural Differences in Perceived Risk of Online Shopping”, Dimensi perceived risk yang digunakan adalah:

1. Social risk; adalah persepsi bahwa sebuah produk yang dibeli mungkin akan mendapat respon negatif (penolakan atau celaan) dari keluarga atau teman.

2. Financial risk; adalah persepsi bahwa sejumlah uang tertentu bisa hilang atau diperlukan untuk membuat sebuah produk bekerja dengan baik

3. Physical risk; adalah persepsi bahwa sebuah produk mungkin berbahaya bagi kesehatan ataupun keselamatan ketika produk tersebut tidak bekerja dengan baik 
4. Performance risk; adalah persepsi bahwa sebuah produk yang dibeli mungkin tidak akan berfungsi sesuai dengan ketentuan seharusnya atau sesuai dengan keinginan.

5. Time risk; adalah persepsi bahwa waktu yang mungkin akan terbuang ketika suatu produk yang dibeli harus diperbaiki terlebih dahulu atau diganti

6. Privacy risk; adalah potensi kehilangan kontrol atas informasi pribadi.

Sedangkan dalam penelitian YE Naiyi (2004) yang berjudul "Dimension of

Customer's Perceived risk in Online Shopping", dimensi Perceived risk yang digunakan adalah;

1. Fraud risk mengacu pada perhatian konsumen mengenai kepercayaan terhadap penjual pada online shopping.

2. Delivery risk mengacu pada perhatian konsumen mengenai proses pengiriman barang.

3. Financial risk mengacu pada perhatian konsumen mengenaik kemungkinan kehilangan uang ketika berbelanja melalui internet.

4. Procees dan time risk mengacu pada pandangan terhadap waktu, kemudahan dan kenyamanan konsumen mengenai berbelanja melalui internet.

5. Product risk mengacu pada kualitas sebuah produk, kinerjanya, kepalsuan produk dan masalah lain yang berhubungan dengan produk tersebut.

6. Privacy risk mengacu pada perhatian konsumen mengenai keamanan dari informasi pribadi ketika berbelanja secara online.

7. Information risk mengacu pada perhatian konsumen terhadap ketiaksesuaian informasi mengenai penjua ataupun produk.

Dalam penelitian ini, penulis membatasi kategori responden pembeli online menjadi lebih spesifik yaitu konsumen yang berbelanja produk pakaian dan acessories secara online melalui media jejaring sosial facebook. Berdasarkan elaborasi dan penyesuaian yang dilakukan maka penulis memasukkan delapan dimensi perceived risk dalam penelitian ini antara lain: Financial Risk, Psycological risk, Time risk, Privacy risk, Fraud risk, Product risk, Information risk, dan Delivery risk.

\section{METODOLOGI PENELITIAN}

\section{A. Populasi, Sampel, dan Pengumpulan Data}

Populasi dalam penelitian ini adalah seluruh mahasiswa Politeknik Negeri Samarinda. Pemilihan sampel dilakukan dengan menggunakan metode purposive sampling dengan kriteria memiliki akun facebook dan pernah melakukan pembelian online di facebook. Data dalam penelitian ini dikumpulkan dengan menggunakan metode survey dengan menyebarkan kuisioner. Pengujian terhadap hipotesis yang diajukan dalam penelitian ini menggunakan regresi berganda dengan sampel minimal 30 orang dan menggunakan alat bantu SPSS sebagai dasar dalam menganalisis untuk membuktikan hipotesis yang diajukan.

\section{B. Instrumen Penelitian}

Variabel dalam penelitian ini terdiri dari perceived risk dan keputusan pembelian. Variabel perceived risk dilihat dari dimensi financial, psychological, time, privacy, fraud, product, information, dan delivery risk. Sedangkan variabel keputusan pembelian dilihat dari tiga tahapan yaitu the input stage, the process 
stage, the output stage. Variabel perceived risk dan keputusan pembelian diukur dengan menggunakan skala likert 1 sampai 6 .

\section{Uji Validitas}

Uji validitas dimaksudkan untuk mengukur sejauh mana instrument yang digunakan benar-benar mengukur yang seharusnya diukur (Cooper dan Schindler, 2003). Suatu alat ukur dikatakan mempunyai validitas tinggi jika alat ukur tersebut menjalankan fungsi ukurnya.

Penelitian ini menggunakan korelasi bivariate untuk menguji validitas konstruk (construct validity). Validitas konstruk menunjukkan seberapa baik hasil yang diperoleh dari penggunaan suatu pengukuran sesuai teori-teori yang digunakan untuk mendefenisikan suatu konstruk (Jogiyanto, 2004).

\section{Uji Reabilitas}

Reabilitas (reability) suatu pengukur menunjukkan akurasi, konsistensi dan ketepatan dari pengukurnya pengukur stabilitas dan konsistensi suatu instrument (Jogiyanto, 2004). Suatu pengukur stabilitas realibel (andal) sepanjang pengukur tersebut menghasilkan hasil-hasil yang konsisten (Cooper dan Schindler, 2003).

Pengujian terhadap reabilitas instrument menggunakan croncbach's alpha yang mencerminkan konsistensi suatu alat ukur. Koefisien reabilitas ditunjukkan oleh koefisien alpha $(\infty)$ croncbach yang berkisar antara nol sampai satu, semakin tinggi nilai koefisien semakin tinggi tingkat keandalan alat ukur yang digunakan. Reabilitas yang sedang antara 0,5 sampai 0,6 sudah cukup untk menjustifikasi sebuah penelitian (Nunally dan Bernstein, 1994).

\section{E. UJI ASUMSI KLASIK}

\section{Uji Multikolinieritas}

Uji multikolinieritas bertujuan untuk menguji apakah model regresi ditemukan adanya korelasi antar variabel bebas (independen). Model regresi yang baik seharusnya tidak terjadi korelasi diantara variabel independen. Jika variabel independen saling berkorelasi, maka veriabel tersebut tidak orthogonal. Variabel orthogonal adalah variabel independen yang nilai korelasi antar sesame variabel independen sama dengan nol.

Untuk mendeteksi ada atau tidaknya multikolineritas didalam model regresi menurut Ghozali (2005) adalah sebagai berikut :

a. Jika antar variable independen ada korelasi cukup tinggi (umumnya diatas $0,90)$. Maka hal ini mengindikasikan adanya multikolonieritas.

b. Multikolonieritas dapat dilihat dari nilai tolerance dan variance inflation factor (VIF). Nilai Cutoff yang umum dipakai untuk menunjukkan adanya multikoloneritas adalah nilai tolerance kurang dari 0,10 atau sama dengan nilai VIF lebih dari 10.

\section{Uji Autokorelasi}

Uji autokorelasi bertujuan menguji apakah dalam model regresi liniear ada korelasi antara kesalahan pengganggu pada periode $t$ dengan kesalahan penganggu pada periode t-1 (sebelumnya). Jika terjadi korelasi, maka dinamakan problem autokorelasi. 
Uji autokorelasi ini menggunakan DW test (Uji Durbin Watson). DW test hanya digunakan untuk uji autokorelasi tingkat satu dan masyarakat adanya konstanta dalam model regresi dan tidak variabel lag di antara variabel independen.

\section{Uji Normalitas}

Uji normalitas bertujuan untuk menguji apakah model regresi, variabel dan penggganggu atau residual memiliki distribusi normal. Uji $t$ dan $F$ mengasumsikan bahwa bahwa nilai residual mengikuti distribusi normal. Jika asumsi ini dilanggar maka uji statistic menjadi tidak valid untuk jumlah sampel kecil. Cara untuk mendeteksi apakah residual berdistribusi normal atau tidak yaitu dengan analisa grafik dan uji statistic.

\section{F. Pengujian Hipotesis}

Pengujian hipotesis penelitian ini menggunakan sofware SPSS 16.00. Data akan diolah untuk mendapatkan informasi deskriptif dan pengujian hipotesis perangkat lunak untuk analisis deskriptif menggunakan SPSS 16.00 for windows

Uji independen sample z test (uji z) digunakan dalam penelitian ini karena sampel yang digunakan lebih dari 30, akan tetapi SPSS tidak menyediakan fasilitas uji z dalam bentuk analisisnya. Walaupun demikian, uji z tetap dengan mudah dilakukan dengan menggunakan uji t, jadi hasil yang didapatkan ditafsirkan sebagai perolehan z; seperti t hitung pada sampel sama besar dengan angka $z$ hitung (Singgih Santoso, 2009)

\section{PEMBAHASAN}

\section{A. $\quad$ Analisis Independent Sample Z Test}

Penelitian ini merupakan penelitian multivariate dimana variabel penelitian yang akan diuji dalam penelitian ini yaitu pengaruh perceived risk terhadap keputusan membeli produk online. Variabel perceived risk diukur dengan menggunakan delapan dimensi sedangkan keputusan membeli diukur dengan menggunakan tahapannya. Seperti yang telah dijelaskan pada bab sebelumnya, uji $Z$ dilakukan dengan menggunakan uji t, jadi hasil yang didapatkan ditafsirkan sebagai perolehan $Z$; seperti t hitung pada sampel besar sama dengan angka $Z$ hitung (Singgih Santoso, 2009). Sehingga data yang ada tetap diolah dengan menggunakan uji t.

Setelah data awal diperoleh dari pengumpulan kuisioner kepada 200 responden yang kemudian yang mengembalikan hanya 150 responden dan data diolah untuk mendapatkan hasil dari analisis independen sample t test

Berdasarkan hasil analisis dapat disimpulkan bahwa perceived risk berpengaruh terhadap keputusan membeli prodek online. Hal ini mengindikasikan bahwa resiko merupakan salah satu alasan yang diperhitungkan dalam melakukan keputusan membeli produk online. Resiko merupakan hal penting yang harus dipertimbangkan dalam melakukan pembelian produk online karena transaksi yang dilakukan antara penjual dan pembeli tidak secara langsung (tatap muka) melainkan melalui media sosial sehingga 
dikhawatirkan menimbulkan resiko yang dapat merugikan, khususnya untuk pihak pembeli.

\section{Dimensi financial}

Pada dimensi ini dapat dilihat hasil yang diperoleh tidak berpengaruh. Hal ini menunjukkan bahwa resiko yang ditimbulkan dari segi keuangan tidak mempengaruhi keputusan pembelian secara online. Produk yang dijual secara online kebanyakan harganya lebih murah jika dibandingkan dengan melakukan pembelian secara langsung, hal ini dikarenakan produk yang dijual secara online memiliki kualitas yang kurang baik sehingga sesuai dengan harga yang ditawarkan.

Selain itu dewasa ini, transaksi jual beli melalui online kebanyakan dilakukan dengan syarat atau perjanjian barang diterima terlebih dahulu oleh pembeli kemudian barulah pembayaran dilakukan. Hal ini dilakukan untuk menghidari resiko khususnya resiko yang akan diderita para pembeli yang melakukan pembelian secara online.

\section{Dimensi psychological}

Pada dimensi ini juga tidak mempengaruhi keputusan pembeli untuk melakukan transaksi, hal ini mengindikasikan bahwa pada dasarnya produk yang ditawarkan pada media online kebanyakan kualitasnya kurang baik karena pembeli hanya melihat produknya melalui media tanpa melihat langsung produk yang akan dibeli. Harga produk yang ditawarkan secara online lebih murah jika dibandingkan dengan harga pasar yang ada, sehingga dapat disimpulkan bahwa harga mencerminkan kualitas dimana ketika produk yang ditawarkan lebih murah maka kualitasnya kurang jika dibandingkan dengan produk yang ditawarkan lebih mahal.

\section{Dimensi waktu}

Pada dimensi ini berdasarkan hasil yang diperoleh tidak berpengaruh terhadap keputusan untuk melakukan pembelian secara online. Ketika melakukan pembelian produk secara online akan terasa sangat berbeda jika dibandingkan dengan melakukan transaksi secara langsung. Jika melakukan transaksi secara langsung maka pembeli akan menerima langsung produknya di saat itu juga namun jika melakukan pembelian secara online maka pembeli tidak akan mendapatkan produknya secara online, hal ini dikarenakan adanya proses pengiriman barang yang membutuhkan waktu, selain itu juga orang yang menjual tidak memiliki barangnya atau merupakan tangan kedua dimana produknya harus dipesan terlebih dahulu kepada penjual asli (pertama) kemudian barulah dikirimkan kepada pembelinya.

\section{Dimensi privacy}

Berdasarkan hasil yang diperoleh yang diperoleh dapat disimpulkan bahwa dimensi privacy tidak berpengaruh terhadap keputusan pembeli untuk melakukan transaski pembelian. Hal ini dapat dilihat bahwa ketika melakukan pembelian secara online maka pembeli harus benar-benar memberikan data diri yang sesungguhnya karena jika tidak maka kegagalan dalam transaksi dapat terjadi, sebagai contoh, alamat rumah atau nomor telepon yang dapat dihubungi 
tidak fiktif karena terkait dengan proses pengiriman barang serta konfirmasi mengenai barang yang telah dikirim sudah diterima atau belum oleh pembeli.

Selain itu data pribadi pembeli produk tidak terjamin aman dan dapat diakses dengan mudah oleh pihak-pihak yang tidak bertanggung jawab (hacker) sehingga dapat menimbulkan kerugian bagi pihak pembeli. Serangan hacker ini sulit untuk dilacak dan perundang-undangan yang diterapkan di Indonesia juga belum memberikan efek jera terhadap pelakunya.

\section{Dimensi fraud}

Berdasarkan hasil yang ada maka dapat ditarik kesimpulan bahwa dimensi fraud ini berpengaruh terhadap keputusan pembelian secara online. Hal ini mengindikasikan bahwa maraknya penipuan yang terjadi membuat pembeli untuk membuat keputusan untuk membeli produk tersebut atau tidak. Penipuan yang terjadi sangat merugikan pembeli, khususnya ketika produk yang diharapkan pembeli tidak sesuai.

Kemudian penjual produk online juga sering melakukan penipuan, misalnya dalam hal produk yang dijual, dimana kebanyakan para penjual mencantumkan akan menerima kembali barang apabila terdapat kerusakan namun dalam kenyataan setelah produk terjual dan ketika dikembalikan kepada penjual, si pembeli akan mengeluarkan biaya tambahan berupa pengiriman kembali barang yang rusak tersebut. Selain itu juga, penjual tidak mau bertanggung jawab atas kerusakan barang yang telah dikirim, hal ini sematamata dikarenakan kerugian yang akan diderita oleh penjual.

\section{Dimensi product risk}

Pada dimensi ini juga tidak mempengaruhi keputusan pembeli untuk melakukan pembelian produk secara online. Hal ini didasarkan pada banyak hal antara lain mengenai produk yang ditawarkan penjual tidak sesuai dengan yang diharapkan pembeli, kualitas produk yang ada juga kurang baik. Kebanyakan produk yang ditawarkan melalui media online juga bukan merupakan produk asli sehingga sering mengecewakan pembelinya.

Dengan adanya beberapa alasan yang telah diungkapkan maka pembeli akan berpikir ulang untuk melakukan transaksi melalui media online. Hal ini juga lah yang membuat pembeli tidak ingin menanggung resiko dalam bertransaksi.

\section{Dimensi informasi}

Hasil yang diperoleh menunjukkan bahwa dimensi informasi berpengaruh terhadap keputusan pembeli untuk melakukan pembelian produk secara online. Informasi mengenai produk yang ditawarkan sangatlah penting bagi pembeli, karena informasi ini menyangkut semua yang berhubungan dengan produk yang ditawarkan.

Informasi yang disampaikan oleh penjual harus jelas dan tidak menimbulkan keragu-raguan. Sehingga ketika pembeli mendapatkan informasi yang baik dari penjual maka akan membuat pembeli untuk melakukan keputusan pembelian. Selain itu informasi mengenai manfaat dan kegunaan produk sangatlah mempengaruhi keputusan pembeli. 


\section{Dimensi delivery}

Berdasarkan hasil yang diperoleh dapat disimpulkan bahwa dimensi ini berpengaruh terhadap keputusan pembelian produk online. Proses pengiriman barang yang dilakukan oleh pihak penjual sangat mempengaruhi keputusan pembelian produk online, hal ini didasarkan pada waktu yang digunakan untuk mengirim barang tersebut, kemudian mengenai jasa pengiriman yang digunakan penjual dalam mengirimkan barangnya. Dimana semua ini menjadi bahan pertimbangan dalam mengambil keputusan untuk melakukan pembelian produk online.

Mengenai proses pengiriman barang pihak pembeli dapat langsung mengkonfirmasi nomor resi pengiriman barang yang telah diberikan oleh penjual melalui jasa pengiriman barang yang digunakan. Hal ini dilakukan oleh pihak pembeli agar dapat mengetahui produk yang dibeli tersebut sudah dikirim atau belum. Jasa pengiriman barang digunakan oleh penjual juga harus terpercaya sehingga ketika produk yang dikirim nantinya akan diterima pembeli dalam keadaan baik tanpa cacat serta tidak membutuhkan waktu yang tidak begitu lama untuk mendapatkan produk tersebut.

\section{KESIMPULAN}

\section{A. Kesimpulan}

Berdasarkan hasil yang diperoleh dapat disimpilkan bahwa secara garis besar perceived risk berpengaruh terhadap keputusan pembelian produk online. Namun ketika menggunakan uji t maka dalam variabel perceived risk yang diukur dengan menggunakan 8 dimensi maka tidak semua dimensi ini mempengaruhi keputusan pembelian produk online.

Pada dimensi financial, psychological, waktu, privacy, dan product risk tidak berpengaruh terhadap keputusan pembelian produk online. Sedangkan untuk dimensi fraud, informasi, dan delivery berpengaruh terhadap keputusan untuk melakukan pembelian produk online

\section{B. Saran}

Berdasarkan kesimpulan yang telah diperoleh dalam penelitian ini maka saran yang dapat diberikan pada penelitian selanjutnya adalah :

1. Penelitian selanjutnya dapat menambah variabel lain selain variabel perceived risk.

2. Penelitian selanjutnya agar dapat menggunakan alat analisis yang lain guna memperkuat maupun menentang hasil penelitian ini.

\section{DAFTAR PUSTAKA}

Cooper, D.R. dan Scindler, P.S. (2003), Business Research Method. Mc Graw Hill, $8^{\text {Th }}$ ED

Cowles, Deborah,.L, Pamela \& Little, Michael W. (2002), Using key informant Insight as a foundation for e- retailing theory development. Journal of Business Reseaarch 55, pp. 629-636. 
Demirdogen, Osman. Sukru Yaprakli. Mustafa Kemal Yilmaz. Jamaluddin Husain. 2010. Customer Risk Perceptions of Internet Banking - A Study in Turkey. Journal of Applied Business Research. Vol 26 No 6

Engel, JF., Blackwell, RD., \& Miniard, PW., 1993. Consumer Behavior. Seventh Edition. USA: The Dryden Press

Ghozali, Imam. (2005), Aplikasi analisis Multivariate dengan Program SPSS. Edisi ketiga, BP Undip.

$\mathrm{Ha}, \mathrm{H}-\mathrm{Y}$. (2002). The Relationships between 3-D Advertisings and Risk Perception on the Web : the Mediating Role of Brand and Emotion. Unpublished Working Paper. UMIST. UK

Jarvenpaa S.L. dan Tractinsky, N. (1999), Cunsumer trust in an Internet store:Across-cultural Validation. Journal of Computer-Mediated Communicatinon, Dec, 1-35

Jogiyanto H.M. (2004), Metode Penelitian Bisnis : Salah Kaprah dan Pengalaman-Pengalaman, BPFE-Yogyakarta.

Ko, Hanjun, Jaemin Jung, Joo Young Kim, dan Sung Wook Shim. 2004. Crosscultural Differences in Perceived Risk of Online Shopiing. Journal of Interactive Advertising. Vol 4 No 2 (Spring), pp.20-29

Kotler, Philip. 2006. Manajemen Pemasaran Edisi 11. Jakarta: $\quad$ PT. Indeks

Loudon, David L. dan Albert J. Della Bitta. 2001. Consumer Behavior: Concepts and Applications. McGraw-Hill Inc., USA

Naiyi, Y.E. (2004). Dimensions of Consumer's Perceived Risk in Online Shopping Journal of Electronic Science and Technology of China Vol.2 No.3

Nunnally, J.C., dan Ira H. Bernstein.(1994), Psycometric Theory. Third Edition, MC Graw Hill, Inc., New York.

Samadi, Mansour dan Ali Yaghoob-Nejadi. 2009. A Survey of the Effect of Consumers Perceived Risk on Purchase Intention in E-Shopping. Business Intelligence Journal. 261-275

Schiffman, Leon \& Kanuk, Leslie Lazer, 2008. Perilaku Konsumen, edisi ketujuh. Jakarta : Indeks.

Stone, RN. and K. Gronhaug. 1993. Perceived Risk: Further Considerations for the Marketing Discipline. European Journal of Marketing. 27 (3). 39-50.

Urbaczewski, A., Jessup L.M., dan Wheeler, B. 2002. Electronic Commerce Research ; A Taxonomy an Shynthesis. Journal of Organizational Computing and Electronic Commerce 12 (4), 263-305

Wilkie, Wieliam, L. 1990. Consumer Behavior. $2^{\text {nd }}$ Edition. Canada. John Wiley\& Sons, Inc 